\title{
Telaah Kritis Makna Hujan dalam Alquran
}

\author{
Arif Iman Mauliddin \\ Pascasarjana UIN Sunan Kalijaga Yogyakarta \\ mahmadou_opnext@yahoo.co.id
}

DOI: http://dx.doi.org/10.29240/alquds.v2i1.382

Submitted: 2018-03-08| Revised: 2018-05-31| Accepted: 2018-06-04

\begin{abstract}
This article examines the meaning of the word rain in the Qur'an. Rain can be interpreted as a blessing bearer, but for some people, rain also interpreted as a disaster, whereas the benefits of rain is very great for life on earth. Research based on the interpretation of Ibn Kathir, Quraish Shihab, and HAMKA by using comparative method. This research found that the word of rain in the Qur'an not only means "rahmat" or gift, but also meaningful as doom or disaster, and natural phenomena. The equation of the three interpretations is that rain is seen as a "rahmat" or a gift because it is considered beneficial for all creatures on the earth, the rain is considered as a punishment because it is held down by God for some time and also because of the descent accompanied by thunder and heavy wind that can damage the earth, and rain as a natural phenomenon because as a process of descending water from sky to earth.
\end{abstract}

Keyword: Rain, Ibn Katsir, Quraish Shihab, HAMKA

\begin{abstract}
Abstrak. Artikel ini mengkaji tentang pemaknaan kata hujan dalam Alquran. Hujan dapat diartikan sebagai pembawa berkah, namun bagi sebagian orang, hujan juga diartikan sebagai musibah, padahal manfaat hujan sendiri sangat besar bagi kehidupan di bumi. Penelaahan berdasarkan penafsiran Ibn Katsir, Quraish Shihab, dan HAMKA dengan menggunakan metode komparatif. Penelitian ini menemukan bahwa kata hujan yang ada dalam Alquran tidak hanya bermakna rahmat atau anugerah saja, namun juga bermakna sebagai azab atau musibah, dan fenomena alam. Persamaan dari tiga tafsir tersebut ialah hujan dipandang sebagai rahmat atau anugerah karena dianggap bermanfaat oleh seluruh mahluk yang ada di muka bumi, hujan dipandang sebagai azab disebabkan ditahan turunnya oleh Allah selama beberapa waktu dan juga karena turunnya yang disertai guntur dan angin lebat yang dapat merusak bumi, dan hujan bermakna sebagai fenomena alam disebabkan turunnya sebagai suatu proses turunnya air dari langit ke bumi.
\end{abstract}

Kata Kunci: Hujan, Ibn Katsir, Quraish Shihab, HAMKA 


\section{Pendahuluan}

Menurut Kamus Besar Bahasa Indonesia (KBBI), hujan ialah titik-titik air berjatuhan dari udara karena proses pendinginan. ${ }^{1}$ Soemarto menjelaskan bahwa daur atau siklus air/hidrologi adalah gerakan air laut ke udara kemudian jatuh ke permukaan tanah dan akhirnya mengalir kembali ke laut. Air laut menguap karena terjadi radiasi matahari menjadi awan kemudian awan yang terjadi oleh penguapan air bergerak di atas daratan karena tertiup oleh angin. Presipitasi yang terjadi karena adanya tabrakan antara butiran-butiran uap air akibat desakan angin yang dapat berbentuk hujan, salju, hujan batu, hujan es dan salju (sleet), hujan gerimis atau kabut. ${ }^{2}$ Proses terjadinya siklus air tersebut, berawal air laut, danau, dan sungai menguap akibat dipanaskan oleh sinar matahari lalu menjadi butir-butir uap air di awan. Jika butir-butir uap air tersebut mengembun, akan terbentuk butiran air hujan yang jatuh ke bumi. Lalu air yang jatuh ke bumi ada yang mengalir di permukaan bumi dan ada yang meresap ke dalam bumi.Air yang mengalir menuju sungai akhirnya bermuara ke laut dan dimulai lagi siklus penguapan air. ${ }^{3}$ Dalam Alquran juga sudah dijelaskan dalam surat al-Rūm ayat 48:

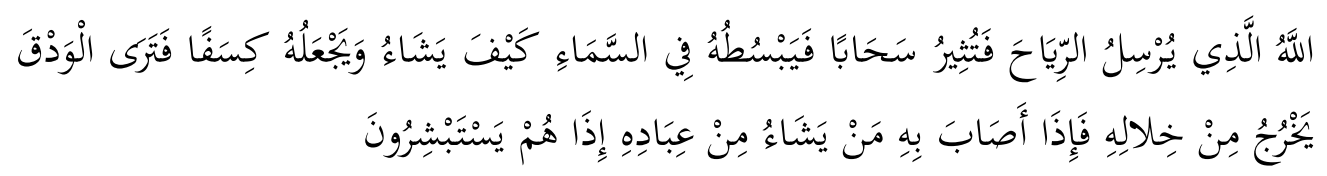

"Allah-lab yang mengirim angin, lalu angin itu menggerakkan awan dan Allah membentangkannya di langit menurut yang Dia kehendaki, dan menjadikannya bergumpalgumpal, lalu engkau lihat bujan keluar dari celab-celabnya, maka apabila Dia menurunkannya kepada hamba-hamban-Nya yang dia kehendaki tiba-tiba mereka bergembira."

Apabila dibaca arti ayat ar-Ruum, terdapat beberapa proses yang berlaku di dalam atmosfer sebelum hujan turun. Yaitu, terjadinya pergerakan awan (dengan bantuan angin), kemudian terjadinya pembentangan awan, selanjutnya awan-awan menggumpal dan pada kondisis tertentu dan hujan turun. ${ }^{5}$

Indonesia sendiri, merupakan negara yang terletak dibawah garis khatulistiwa sehingga memiliki iklim tropis, jelasnya iklim tropis basah. Hal tersebut juga dipengaruhi oleh bentuk negara Indonesia yang merupakan negara

509.

${ }^{1}$ Dedy Sugono, Kamus Besar Bahasa Indonesia (Jakarta: Gramedia Pustaka Utama, 2008),

${ }^{2}$ Eny Yulianti and Elok Kamilah Hayati, Kasib Sayang Allah Dalam Air Hujan (Malang: UIN-Malang Press, 2008), 3.

${ }^{3}$ Ridwan Abdullah Sani, Sains Berbasis Al-Qur'an (Jakarta: Bumi Aksara, 2015), 161-62.

${ }^{4}$ Tim Syamil, Al-Qur'an Terjemah Al-Syamil (Bandung: Syaamil Qur’an, 2012), 409.

${ }^{5}$ Yulianti and Hayati, Kasib Sayang Allah Dalam Air Hujan, 14. 
kepulauan, dan sebagian besar daratannya dikelilingi oleh lautan samudera, karena itulah di Indonesia terdapat iklim laut yang bersifat lembab dan banyak mendatangkan hujan. ${ }^{6}$ Namun dengan banyaknya air hujan yang turun tersebut, tidak selalu membuat sebagian masyarakat Indonesia berpandangan bahwa itu rahmat/anugerah, malahan menganggapnya sebagai musibah karena merasa dirugikan dengan turunnya hujan. Misalnya saja yang sering kita lihat banjir yang melanda Jakarta, tak sedikit masyarakat mengeluh karena banjir tersebut sehingga mereka selalu beranggapan hujan yang turun tersebut sebagai musibah. Sedangkan Wakil Gubernur Jakarta (Sandiaga Uno) mengatakan bahwa "Allah lagi ngirimin hujan. Kalau kita punya sistem yang baik, hujan justru harus menjadi berkah bagi kita", bahkan menurutnya hujan deras yang turun mengguyur ibu kota selama dua tersebut merupakan nikmat yang harus disyukuri. $^{7}$

Dalam Alquran sendiri ternyata banyak ayat-ayat yang membahas masalah hujan, terlepas dari makna, derivasi, dan konotasinya. Karena di Indonesia masyarakatnya mayoritas muslim, ditambah dengan Alquran sebagai fungsi utama dan muslim Indonesia yang cendrung berikap praksis, sehingga Alquran masuk pada setiap dimensi kehidupan. Bahkan membantu mengkontruksi stigma dan paradigma terkait dengan bagaimana masyarakat memandang fenomena alam yang salah satunya ialah hujan.

Dari beberapa penelitian, terkait pemaknaan dan penafsiran ayat-ayat tentang hujan, seperti "Makna Perkataan Hujan dalam Alquran Berdasarkan Konteks Situasi" 1 yang ditulis oleh Asrul Azam Shafie dkk, "Kata Bermakna Hujan dalam Alquran (Tinjauan Semantik dan Stilistika)" 9 oleh Ahmad Khalwani, dkk, dan "Proses Turunnya Hujan dalam Alquran: Telaah Penafsiran

${ }^{6}$ Oktolina Simatupang, "Pesan Tentang Edukasi Bencana Dalam Film 'Nyanyian Musim Hujan," Journal Penelitian dan Pengembangan Komunikasi dan Informatika 17, no. 2 (2016): 89, doi:http://dx.doi.org/10.31346/jpkp.v17i2.706.

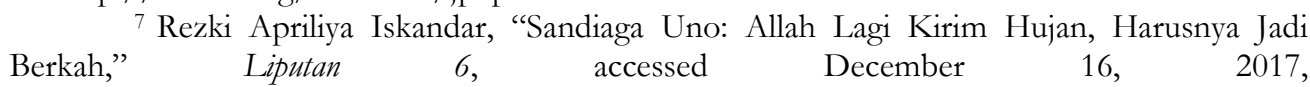
https://www.liputan6.com/news/read/3192188/sandiaga-uno-allah-lagi-kirim-hujan-harusnyajadi-berkah.

${ }^{8}$ Mohd Sukki Othman, Asrul Azam Shafie, and Muhd Zulkifli Ismail, "Makna Perkataan Hujan Dalam Al-Quran Berdasarkan Konteks Situasi," Jurnal Kemanusiaan 15, no. 1-S November 27 , 2017), https://jurnalkemanusiaan.utm.my/index.php/kemanusiaan/article/view/260.

${ }^{9}$ Ahmad Khalwani, Mohamad Yusuf Ahmad Hasyim, and Ahmad Miftahuddin, "Kata Bermakna Hujan Dalam Al-Quran (Tinjauan Semantik Dan Stilistika)," Lisanul' Arab: Journal of Arabic Learning and Teaching 6, no. 1 (May 15, 2017): 1-5. 
Tantawi Jauhari dalam Tafsir Jawāhir fi Tafsīr Qur'an al-Karīm”10, penulis belum menemukan tulisan yang secara kritis merekonstruksi term hujan di dalam Alquran dengan pendekatan komparatif. Dalam tulisan Asrul Azam Shafie dkk lebih cenderung menelisik korelasi variasi kata hujan (matar, ghaith, soyyib, wabil,dan wadq) dengan konteks situasi. Demikian pula artikel dari Ahmad Khalwani dkk, aspek linguistik dalam memahami term hujan lebih mendapatkan porsi. Sedangkan, penelitian yang terakhir hanya terfokus pada suatu kitab tafsir dan menekankan pada proses turunnya hujan.

Adapun penelitian ini akan lebih diarahkan untuk merekonstruksi pemaknaan term hujan melalui pendekatan komparatif. Pertanyaan yang ingin dijawab dalam tulisan ini ialah apakah makna hujan sebagai anugerah itu sudah sesuai dengan apa yang dimaksudkan oleh Alquran? Untuk menjawab pertanyaan tersebut, penulisan ini akan terbagi ke dalam beberapa pembahasan. Bagian pertama memaparkan penafsiran ayat-ayat Alquran tentang hujan, yang mana penafsiran ini merujuk kepada tiga kitab tafsir yaitu Tafsir Ibnu Katsir, Tafsir al-Misbah, dan Tafsir al-Azhar. Kedua, menganalisis penafsiran dari tiga ulama' tafsir tersebut terhadap ayat-ayat yang membahas tentang hujan.Ketiga, memberikan kesimpulan dari hasil analisis penafsiran ayat-ayat Alquran yang membahas tentang hujan.

\section{Profil Singkat Mufassir}

1. Tafsir Ibn Katsir

Nama lengkap dari pengarang kitab Tafsir Ibnu Katsīr ialah Imaduddīn Ismail bin Umar Katsīr Al-Bashri Al-Dimisqī Al-Faqih Al-Syāfî̀. Beliau lahir pada tahun 705 di Timur Bashri wilayah bagian Damaskus. Ibn Katsir berguru kepada banyak ulama', salah satunya yaitu Syaikh Burhanuddin Al-Fazarī dan Kamaluddīn bin Qadhy Suhbah, Ibn Katsir mengokohkan ilmunya. Kemudian ia menyunting putri Al-Hafidz Abu Al-Hajjāj Al-Muzzī, gurunya dalam bidang hadis. Ibn Katsir juga banyak mengambil ilmu dari Ibnu Taimiyyah dan membaca Ushul hadis dengan Al-Ashfahanī.Imam Dzahabī mengatakan tentang Ibn Katsir bahwa beliau adalah seorang imam, mufti, pakar hadis, spesialis fiqih, dan ahli hadis yang cermat dan mufassir yang kritis. ${ }^{11}$

Diantara tulisannya yang paling terkenal adalah kitab Tafsir Ibn Katsir atau Tafsir Alquran al-Adzim. Tafsir Ibn Katsīr tersebut merupakan Tafsir bil al-Ma'tsur

10 Ahmad Taufiq Muharam, "Proses Turunnya Hujan Dalam Al-Qur'an: Telaah Penafsiran Tantawi Jauhari Dalam Tafsir Jawāhir Fi Tafsīr Qur’an Al-Karīm” (UIN Sunan Kalijaga, suka.ac.id/1681/1/BAB\%20I\%2C\%20V\%2C\%20DAFTAR\%20PUSTAKA.pdf. http:/ / digilib.uin-

${ }^{11}$ Muhammad Sofyan, Tafsir Wa Al-Mufassirun (Medan: Perdana Publishing, 2015), 52 53. 
yang terkenal dan meduduki peringkat kedua setelah tafsir Ibn Jarīr al-Thabarī. ${ }^{12}$ Menurutnya, metodologi yang tepat dalam menafsirkan Alquran ialah, 1) Tafsir Alquran terhadap Alquran itu sendiri, 2) menggunakan sunnah yang merupakan penjelas Alquran. Dalam penafsirannya Ibn Katsīr terkadang menjelaskan beberapa aturan-aturan lingusitik, i'rab, nahwu, dan aspek balaghah. Pada dasarnya dalam pembahasannya tafsir ini menjelaskan hanya sekedarnya saja. Kemudian oleh para ulama yang lain memperdalam topik-topik ayat yang ditafsirkan sesuai dengan keinginana secara terperinci. Dengan tujuan untuk memperdalam pokok-pokok ilmu tafsir yang sesuai keilmuan dan pemahaman yang dimiliki oleh ulama. ${ }^{13}$

\section{Tafsir al-Misbah}

Penulis dari tafsir al-Misbah ini adalah M. Quraish Shihab, ia dilahirkan pada 16 Februari di Kabupaten Sidenreng Rappang, Sulawesi Selatan. Quraish Shihab memulai pendidikan menengahnya di Malang tepatnya di Pondok Pesantren Dar al-Hadist al-Fiqhiyyah. Pada tahun 1958 ia melanjutkan pendidikannya di al-Azhar, pada tahun 1967 dia meraih gelar Lc pda Fakultas Ushuluddin Jurusan Tafsir Hadist Universitas al-Azhar. Kemudian ia melanjutkan pedidikannya di fakultas yang sama, sehingga tahun 1969 ia meraih gelar MA untuk spesialis Tafsir Alquran. ${ }^{14}$

Tafsir al-Misbah merupakan karyanya yang paling monumental.Kitab tersebut berisi 15 volume yang secara lengkap memuat penafsiran 30 juz ayatayat dan surah-surah Alquran.Metode penulisan tafsir tersebut ialah tablili, yaitu menafsirkan ayat per ayat sesuai dengan urutannya dalam mushaf. Menurut Quraish Shihab kitab tafsir tersebut diselesaikan selama empat tahun; dimulai di Mesir pada hari Jumat 4 Rabi'ul Awwal 1420 H/18 Juni 1999 dan selesai di Jakarta, Jumat 5 September 2003. ${ }^{15}$

${ }^{12}$ Nurdin Nurdin, “Analisis Penerapan Metode Bi Al-Ma'sur Dalam tafsir Ibnu Katsir Terhadap Penafsiran Ayat-Ayat Hukum," Asy-Syir'ah 47, no. 1 (January 1, 2013): 86-87, doi:10.14421/asy-syir'ah.2013.\%x.

${ }^{13}$ Sofyan, Tafsir Wa Al-Mufassirun, 55-56.

14 Atik Wartini, "Corak Penafsiran M. Quraish Shihab Dalam Tafsir Al-Misbah," HUNAFA: Jurnal Studia Islamika 11, no. 1 (June 19, 2014): 115, doi:10.24239/jsi.v11i1.343.109126.

15 Muhammad Iqbal, "Metode Penafsiran Al-Qur'an M. Quraish Shihab," TSAQAFAH 6, no. 2 (November 30, 2010): 258, doi:10.21111/tsaqafah.v6i2.120. 


\section{Tafsir al-Azhar}

Pengarang dari kitab Tafsir al-Azhar ini adalah HAMKA (Haji Abdul Malik Karim Amrullah) lahir pada tanggal 16 Februari 1908 M bertepatan pada tanggal 13 Muharram $1326 \mathrm{H}$. Abdul Malik atau HAMKA memulai pendidikannya dengan belajar membaca Alquran di rumah orang tuanya sampai khatam. Kemudian mereka sekeluarga pindah dari Maninjau ke Padang Panjang yang merupakan basis pergerakan kaum muda Minang Kabau pada 1914 M. Singkatnya secara keseluruhan masa pendidikan formal yang pernah di tempuh HAMKA hanya sekitar tujuh tahun lebih, yaitu antara tahun 1916-1924. ${ }^{16}$

Sebagai salah seorang yang ahli dalam bidang agama, sejarah, budaya, sastra dan politik, Buya HAMKA banyak menuangkan ilmu pengetahuannya ke dalam karya tulis.Salah satu karyanya yang terkenal ialah kitab Tafsir al-Azhar. Dinamakan al-Azhar karena serupa dengan nama masjid yang didirikan di tanah halamannya, kebayoran baru. Tafsir al-Azhar sendiri ditulis berasaskan pandangan dan kerangka manhaj yang jelas dengan merujuk kepada kaedah Bahasa Arab, tafsir salaf, asbāb al-nuqul, nasikh mansükh, ilmu Hadis, ilmu fiqh dan sebagainya. Adapun sistematika penafsiran Buya HAMKA ialah menggunakan metode tartīb utsmani, menfasirkan ayat secara runtut berdasarkan Mushaf Utsmani yang dimulai dari surat al-Fatihah sampai surat al-Nās, metode tersebut disebut juga dengan metode tabliti. ${ }^{17}$

\section{Analisis Penafsiran}

Salah satu faktor yang menjadi pertimbangan penulis memilih metode muqaran (komparatif) dalam menganalisis makna term hujan, adalah untuk mendemonstrasikan kemukjizatan Alquran secara redaksional dan mengeksplanasi kandungan Alquran lebih komprehensif.

Secara terminologi, metode muqaran dipahami sebagai proses penafsiran dengan membandingkan ayat-ayat Alquran yang memiliki persamaan atau kemiripan redaksi, yang berbicara tentang masalah atau kasus yang berbeda, atau memiliki redaksi yang berbeda bagi masalah atau kasus yang sama. Ruang lingkup metode ini lebih kepada mengkomparasikan suatu ayat Qur'an dengan ayat lainnya yang tampaknya bertentangan, serta mengadukan pendapatpendapat ulama' tafsir menyangkut penafsiran ayat-ayat Al-Quran. ${ }^{18}$

${ }^{16}$ Avif Alfiyah, "Metode Penafsiran Buya Hamka Dalam Tafsir Al-Azhar," Jurnal Ilmiah Ilmu Ushuluddin 15, no. 1 (2016): 25-27, doi:http://dx.doi.org/10.18592/jiiu.v15i1.1063.

${ }^{17}$ Ibid., 27-29.

${ }^{18}$ Mula Salim, Metodologi Ilmu Tafsir (Sleman: Teras, 2005), 85. 
Dalam penelitian ini penulis membandingkan teks ayat-ayat Alquran yang memiliki persamaan atau kemiripan redaksi dalam dua kasus atau lebih, atau disebut dengan metode muqaran antara ayat dengan ayat. ${ }^{19}$

Dari berbagai ayat-ayat yang membahas hujan dalam Alquran, penulis menfokuskan kepada enam ayat dan mengategorikan dalam tiga bagian. Pertama, hujan sebagai rahmat/anugerah pada Q.S al-Anfal ayat 11 dan Q.S al-Syūra ayat 28. Kedua, hujan sebagai azab atau musibah pada suratHud ayat 44 dan al-Ahqaf ayat 24. Ketiga, hujan sebagai fenomena alam pada Q.S al-Nūr ayat 43 dan Q.S al-Rūm ayat 48 .

\section{Hujan sebagai Rahmat}

Surat al-Anfäl ayat 11

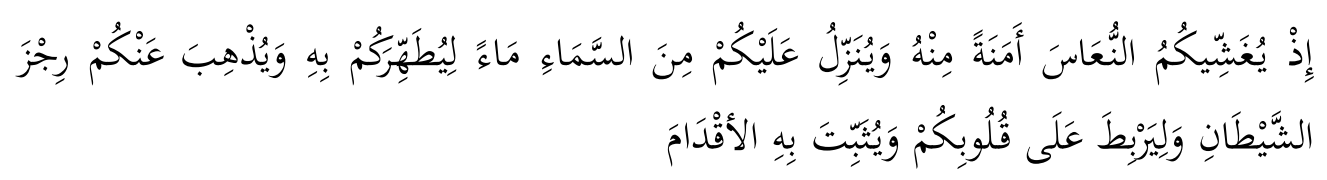

(Ingatlab), ketika Allah menjadikan kamu mengantuk sebagai suatu penentraman daripada-Nya, dan Allah menurunkan kepadamu bujan dari langit untuk menyucikan kamu dengan bujan itu dan mengbilangkan dari kamu gangguan-gangguan setan dan untuk. menguatkan hatimu dan memperteguh dengannya telapak kaki (mu).

1. Tafsir Ibn Katsir

Adapun penafsiran kata hujan pada ayat tersebut bahwa Allah telah menurunkan hujan yang lebat untuk minum dan bersuci oleh kaum muslim. Allah pun menghilangkan godaan setan dari mereka, kemudian tanah berpasir tersebut menjadi kuat dan padat oleh karena siraman air hujan yang lebat. Sehingga orang-orang dapat dengan mudah melaluinya. ${ }^{20}$

${ }_{19}$ Ruang linkup metode tafsir muqaran: pertama, membandingkan teks ayat-ayat alQur'an yang memiliki persamaan atau kemiripan redaksi dalam dua kasus atau lebih, dan atau memiliki redaksi yang berbeda bagi kasus yang sama. Kedua, membandingkan ayat al-Qur'an dengan hadits yang pada lahirnya terlihat bertentangan. Ketiga, membandingkan berbagai pendapat ulama tafsir dalam menafsirkan al-Qur'an.Metode ini diharapkan dapat melahirkan pemahaman komprehensif terhadap ayat-ayat al-Qur'an. Lihat: Nasiruddin Baidan, Metode Penafsiran Al-Qur'an (Yogyakarta: Pustaka Pelajar, 2002), 64-65.

${ }^{20}$ Imaduddin Abi al-Fida Isma’il ibn Katsir, Tafsir Ibnu Katsir, 9 Jakarta: Pustaka Imam Syafi'i, 2004), 354. 


\section{Tafsir al-Misbah}

Quraish Shihab dalam kitab tafsirnya menjelaskan, bahwa hujan merupakan salah satu nikmat Allah Swt yang diturunkan untuk hamba-Nya dari langit. Kemudian dengan air hujan tersebut dapat memenuhi kebutuhan minum hamba-Nya di padang pasir, dan air tersebut digunakan untuk berwudhu atau mandi wajib dan sunnah. Serta menghilangkan kotoran yang dilakukan oleh setan, yakni hadas besar, atau ganguan setan yang menanamkan pesimisme, dan sebagainya.Lalu dengan turunnya air hujan tersebut, pasir menjadi lebih mantap dan padat, sehingga kamu dapat berjalan lebih cepat dan tidak terbenam oleh pasir. ${ }^{21}$

\section{Tafsir al-Azhar}

Buya HAMKA menjelaskan kata hujan pada ayat tersebut ialah, dengan turunnya hujan sumur-sumur menjadi berisi, penampungan air jadi penuh, dan pasir yang terserak yang dapat mengikat kaki dalam perjalanan menjadi keras sehingga mudah untuk dipijak. Buya HAMKA juga menjelaskan beberapa faedah yang dapat dirasakan hambanya karena turunnya hujan: pertama, mereka dapat membersihkan diri yang bersih, dan fikiranpun terbuka. Kedua, segala kotoran setan jadi sirna, sebab apabila melihat kondisi sekeliling kotor karena kurang air maka bersaranglah pengaruh setan dalam hati.Ketiga, kegembiraan karena adanya air menjadi rata pada semuanya sehingga hatipun bertambah bersatu-padu.Keempat, dengan keadaan bumi yang keras diinjakkan, hati pun bertambah bulat menghadapi musuh. ${ }^{22}$

\section{Analisis Komparatif}

Secara umum penafsiran dari tiga mufassir terhadap ayat diatas ialah, air hujan yang Allah turunkan dari langit merupakan suatu rahmat atau anugerah yang Allah turunkan hambanya. Dengan hujan yang Allah turunkan tersebut kaum muslimin dapat menggunakannya untuk minum, sumur-sumur menjadi penuh, dapat digunakan untuk bersuci, dan juga pasir-pasir yang lembek/lembut menjadi mudah dilalui karena menjadi padat karena air hujan.

Setelah penulis cermati tiga penafsiran mufassir tersebut terdapat indikasi bahwa hujan dalam ayat ini sebagai rahmat/anugerah. Indikasi tersebut adalah, bahwa dengan turunnya air hujan, kaum muslimin dapat menggunakannya untuk menyucikan diri, minum, dan juga membuat kaum muslimin jadi mudah berjalan diatas pasir yang lembut. Adapun perbedaan yang mencolok dari tiga penafsiran tersebut ialah penafsiran HAMKA. Dalam penafsirannya HAMKA menyebutkan beberapa faedah dari turunnya air hujan

${ }^{21}$ M. Quraish Shihab, Tafsir Al-Misbah, 4 (Jakarta: Lentera Hati, 2002), 477.

${ }^{22}$ Hamka, Tafsir Al-A₹̣har, 3 (Jakarta: Gema Insani Press, 2015), 671-72. 
tersebut. Pertama, mereka dapat mensucikan diri yang bersih, serta pikiranpun terbuka. Kedua, segala kotoran setan akan sirna, karena apabila melihat kondisi sekitar kotor karena kurang air maka akan bersaranglah pengaruh setan dalam hati. Ketiga, menjadi gembira karena adanya air menjadi rata, sehingga hatipun bertambah bersatu-padu. Keempat, dengan bumi yang keras diinjakkan, hati pun bertambah bulat untuk menghadapi musuh.

Surat al-Syüra ayat 28

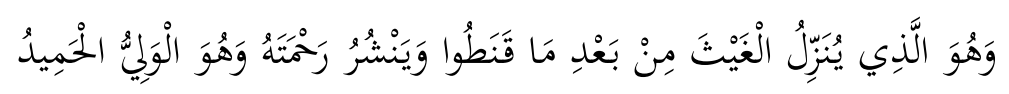

Dan Dialah Yang menurunkan bujan sesudah mereka berputus asa dan menyebarkan rahmat-Nya.Dan Dialah Yang Maha Pelindung lagi Maba Terpuji.

\section{Tafsir Ibn Katsir}

Ibn Katsir dalam kitabnya menafsirkan bahwa dengan turunnya hujan tersebut Allah menurunkan rahmatNya atau menyamakan kedudukannya setelah mereka berputus asa. Allah-lah yang mengatur segala urusan makhluk-Nya dengan sesuatu yang memberikan manfaat bagi dunia dan akhirat mereka. ${ }^{23}$

2. Tafsir al-Misbah

Adapun penafsiran Quraish Shihab terhadap makna hujan dalam ayat tersebut ialah, bahwa hujan ialah rahmat yang Allah turunkan setelah pupusnya harapan mereka yang menghadapi kekeringan serta tanah yang tandus.Allah menurunkannya sebagai tanda kasih sayang kepada hamba-hamba-Nya, Dia juga yang mengatur lokasi-lokasi turunnya guna menyebarkan rahmat-Nya. Oleh karenanya manusia, hewan, tumbuh-tumbuhan, tanah tandus, dan lain-lain dapat memperoleh manfaatnya. ${ }^{24}$

\section{Tafsir al-Azhar}

Buya HAMKA menjelaskan bahwa dalam sewaktu-waktu Allah bisa saja menurunkan rahmatNya yaitu hujan ke bumi, dalam beberapa menit saja harapan yang hampir putus berhari-hari, berminggu-minggu, pulih kembali. Rahmat tercurahkan dimana-mana. Seringkali petolongan Allah datang di luar dugaan dan perhitungan kita. ${ }^{25}$

${ }^{23}$ Imaduddin Abi al-Fida Isma’il ibn Katsir, Tafsir Ibnu Katsir, 7 Jakarta: Pustaka Imam Syafi'i, 2004), 253-54.

${ }^{24}$ Shihab, Tafsir Al-Misbah, 4, 164.

${ }^{25}$ Hamka, Tafsir Al-Az̧bar, 8 (Jakarta: Gema Insani Press, 2015), 205. 


\section{Analisis Komparatif}

Tiga penafsiran diatas pada umumnya mengatakan bahwa hujan yang turun dari langit merupakan rahmat dari Allah Swt berikan untuk hamba-Nya yang membutuhkan. Dengan air hujan, semua mahkluk yang ada di bumi memperoleh manfaatnya. Manusia dapat menggunakannya sebagai air minum, bersuci, dan sebagainya, sedangkan tumbuh-tumbuhan yang kering menjadi segar kembali, dan tanah yang tandus menjadi basah dan dapat ditanam tumbuhtumbuhan. Tidak ada perbedaan penafsiran dari ketiga mufassir.

\section{Hujan sebagai Azab/Musibah}

Surat Hud ayat 44

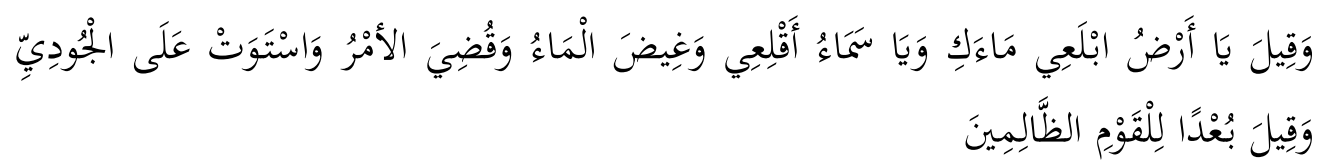

Dan difirmankan: "Hai bumi telanlah airmu, dan hai langit (bujan) berbentilab," Dan air pun disurutkan, perintahpun diselesaikan dan babtera itu pun berlabub di atas bukit Judi, dan dikatakan: "Binasalab orang-orang yang lalim.

\section{Tafsir Ibn Katsir}

Ibn Katsir menjelaskan dalam kitab tafsirnya bahwa kata hujan pada ayat tersebut merupakan sebuah hukuman yang Allah berikan, dengan cara memerintahkan awan untuk menahan hujan turun dan air-air yang berada dibumi pun diserap. ${ }^{26}$

\section{Tafsir al-Misbah}

Quraish Shihab menafsirkan makna hujan dalam ayat tersebut sebagai musibah yang diturunkan oleh Allah Swt kepada para pendurhaka yaitu kaum Nabi Nuh. Allah menghukumnya dengan cara berhentinya mencurahkan hujan yang Allah tumpahkan dengan sangat deras. ${ }^{27}$

\section{Tafsir al-Azhar}

Dalam tafsirnya dijelaskan bahwa hujan pada ayat tersebut merupakan suatu azab bagi satu kaum, yang mana kaum tersebut tidak diberi hujan dan airair yang tergenangpun disurutkan. ${ }^{28}$

4. Analisis Komparatif

\footnotetext{
${ }^{26}$ Imaduddin Abi al-Fida Isma'il ibn Katsir, Tafsir Ibnu Katsir, 4 (Jakarta: Pustaka Imam Syafi'i, 2004), 350.

${ }^{27}$ Shihab, Tafsir Al-Misbah, 4, 635.

${ }^{28}$ Hamka, Tafsir Al-Azhar, 4 (Jakarta: Gema Insani Press, 2015), 557-58.
} 
Secara garis besar persamaan penafsiran pada ayat diatas ialah, Allah SWT memberikan hukuman/azab kepada hambanya dengan cara menahan air hujan untuk tidak turun kebumi dan menyerap kembali air-air yang berada di bumi. Alasan penulis untuk mengategorikan ayat tersebut sebagai musibah sangat jelas sekali karena di dalam ayat tersebut makna dari hujan itu ialah azab yang Allah berikan dengan cara menahannya turun ke bumi.

Surat al-Ahqaf ayat 24

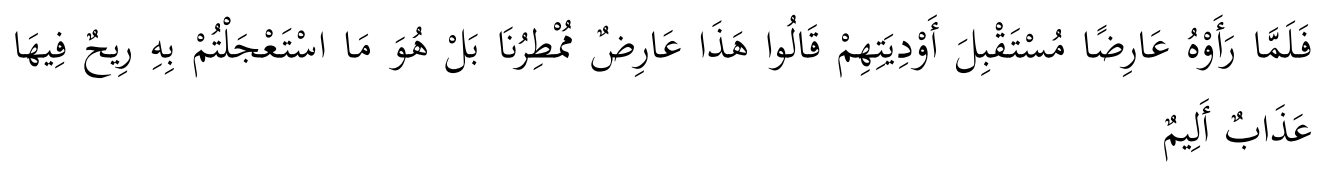

Maka tatkala mereka melibat azab itu berupa awan yang menuju ke lembah-lembah mereka, berkatalah mereka: "Inilah awan yang akan menurunkan bujan kepada kami". (Bukan)! bahkan itulah azab yang kamu minta supaya datang dengan segera (yaitu) angin yang mengandung azab yang pedih.

1. Tafsir Ibn Katsir

Adapun kata hujan dalam ayat tersebut ialah sebuah azab bagi suatu kaum yang mengira bahwa hujan tersebut diturunkan untuk menghidupkan kembali kekeringan yang menimpa mereka.Namun ternyata hujan tersebut sebagai azab yang diturunkan Allah untuk kaum tersebut. ${ }^{29}$

2. Tafsir al-Misbah

Dalam penafsirannya, Quraish Shihab mengatakan bahwa hujan dalam ayat diatas ialah suatu azab yang Allah berikan terhadap hamba-Nya. Kaum tersebut mengira hujan yang diturunkan ialah rizki untuknya, namun ternyata hujan tersebut sebagai hukuman dengan angin yang mengandung siksa yang pedih serta dapat menghancurkan apa yang berdapa dihadapannya. ${ }^{30}$

\section{Tafsir al-Azhar}

Kata hujan pada ayat tersebut dalam penafsiran Buya HAMKA ialah sebagai azab yang Allah turunkan untuk Hud. Mereka mengira hujan yang turun tersebut adalah rahmat yang Allah turunkan.Namun, ternyata hujan yang diturunkan ialah azab yang disertai dengan taufan, halilintar, dan guruh yang menghancurkan bumi. ${ }^{31}$

\footnotetext{
${ }^{29}$ ibn Katsir, Tafsir Ibnu Katsir, 7, 371.

${ }^{30}$ Shihab, Tafsir Al-Misbah, 4, 429.

${ }^{31}$ Hamka, Tafsir Al-Az̧ar, 8, 310.
} 


\section{Analisis Komparatif}

Ketiga mufassir mengatakan bahwa hujan yang diturunkan ke bumi merupakan salah satu azab/musibah yang Allah berikan dengan cara mengirimnya dengan guntur dan angin yang besar kepada hamba-Nya. Dengan turunya hujan disertai dengan guntur dan angin yang kuat tersebut, sangat jelas sekali bahwa hujan pada ayat ini mengindikasikan sebagai azab atau musibah.

\section{Hujan sebagai Fenomena Alam}

Surat al-Nür ayat 43

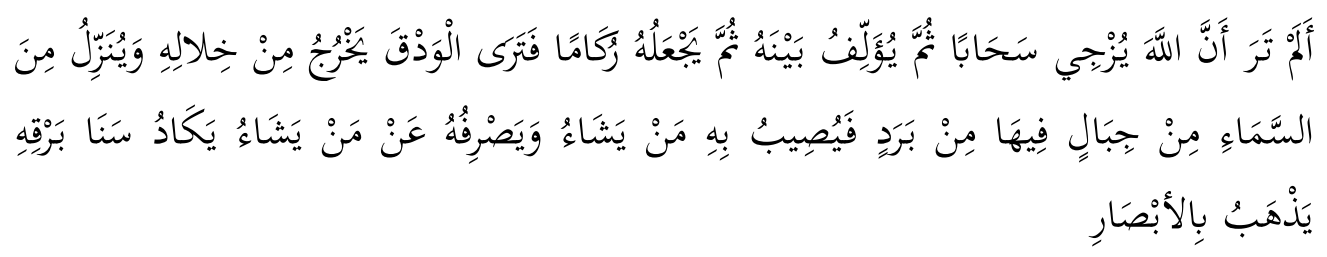

Tidakkah kamu melihat bahwa Allah mengarak awan, kemudian mengumpulkan antara (bagian-bagian)-nya, kemudian menjadikannya bertindih-tindih, maka kelihatanlah olehmu bujan keluar dari celab-celabnya dan Allah (juga) menurunkan (butiran-butiran) es dari langit, (yaitu) dari (gumpalan-gumpalan awan seperti) gunung-gunung, maka ditimpakanNya (butiran-butiran) es itu kepada siapa yang dikehendaki-Nya dan dipalingkan-Nya dari siapa yang dikehendaki-Nya. Kilauan kilat awan itu hampir-hampir menghilangkan penglibatan.

\section{Tafsir Ibn Katsir}

Dengan kekuasaan-Nya, Allah dapat mengarak awan dan mengumpulkannya setelah berserakan disana sini. Kemudian Allah mengeluarkan hujan dari celah-celahnya, sebagaimana Ibn Katsir menjelaskan bahwa air yang diturunkan terdapat dua jenis hujan, yaitu hujan biasa dan hujan es. Lalu diturunkannya hujan biasa dengan hujan es tersebut kepada yang dikehendaki-Nya sebagai rahmat dari-Nya. Namun hujan es yang diturunkan Allah tersebut dapat pula merusak buah-buahan dan menghancurkan tanam-tanaman juga pepohonan mereka. $^{32}$

32 Imaduddin Abi al-Fida Isma'il ibn Katsir, Tafsir Ibnu Katsir, 6 (Jakarta: Pustaka Imam Syafi'i, 2004), 70-71. 


\section{Tafsir al-Misbah}

Hujan yang diturunkan Allah Swt merupakan salah satu kebesarannya. Turunnya air hujan ke bumi bumi juga melalui proses, yang bermula dari air laut dan sungai darat, kemudian menguap lalu turun kembali ke darat. Kemudian hujan yang diturunkan melalui rangkaian proses tersebut, diturunkan kepada yang Allah kehendaki. ${ }^{33}$

\section{Tafsir al-Azhar}

Turunnya hujan pada ayat tersebut melalui beberapa proses yaitu awan dikumpulkan dengan timbangan aliran angin udara, lalu menjadikannya suatu tumpukan. Setelah awan yang bergerak itu terkumpul, timbullah mega yang mendung dan hitam karena mengandung hujan. Kemudian keluarlah hujan dari celah-celah awan. Terkadang dari langit turun segumpalan awan besar seperti gunung yang di dalamnya mengandung salju yang ditumpahkan ke atas sesuai yang dikehendaki-Nya. ${ }^{34}$

\section{Analisis Komparatif}

Ketiga mufassir sama mengatakan bahwa hujan yang turun ke bumi melalui beberapa proses yang tak lepas dari kekuasaan Allah Swt yaitu, diawali dari air dari laut dan sungai, kemudian menyatunya awan-awan yang berserakan, setelah itu menguap dan keluar air hujan dari celah-celah awan. Turunnya hujan dan beberapa proses yang dijelaskan menjadikan alasan penulis untuk mengategorikan ayat tersebut sebagai kejadian fenomena alam, dan tidak ada perbedaan yang menonjol diantara tiga penafsiran terhadap ayat diatas.

Surat al-Rüm ayat 48

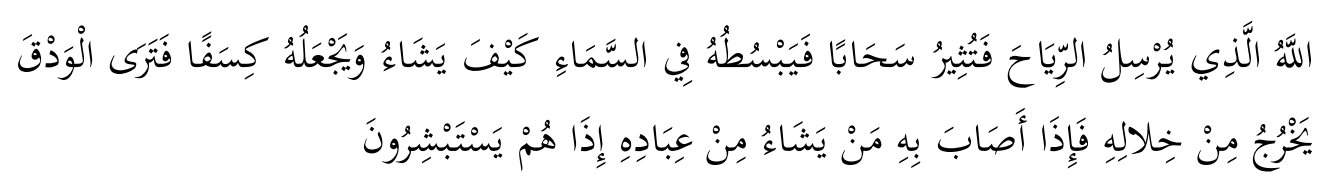

Allah, Dialah yang mengirim angin, lalu angin itu menggerakkan awan dan Allah membentangkannya di langit menurut yang dikehendaki-Nya, dan menjadikannya bergumpal-gumpal; lalu kamu lihat bujan ke luar dari celab-celabnya, maka apabila bujan itu turun mengenai hamba-hamba-Nya yang dikehendaki-Nya tiba-tiba mereka menjadi gembira.

${ }^{33}$ M. Quraish Shihab, Tafsir Al-Misbah, 9 (Jakarta: Lentera Hati, 2002), 369.

${ }^{34}$ Hamka, Tafsir Al-Ažhar, 6 (Jakarta: Gema Insani Press, 2015), 313. 


\section{Tafsir Ibn Katsir}

Dalam kitabnya Ibn Katsir menjelaskan bagaimana proses penciptaan awan sesuai dengan apa yang dikehendakinya. Lalu awan tersebut mengeluarkan hujan dari celah-celahnya, dan dengan turunnya hujan tersebut hamba-hambaNya menjadi gembira karena kebutuhan mereka terhadapnya. ${ }^{35}$

2. Tafsir al-Misbah

Quraish Shihab menjelaskan dalam kitabnya bahwa hujan yang diturunkan Allah kebumi, melalui beberapa proses yaitu dengan mengirimkan angin yang menggerakkan awan, kemudian melalui hukum-hukum alam yang telah ditetapkan-Nya awan tersebut membentang dilangit dengan bentuk yang bergumpal-gumpal, lalu dengan izin Allah keluarlah dari celah-celahnya air hujan kepada siapa yang dikehendakinya. Ayat diatas menggambarkan tentang proses terjadinya hujan yang diawali dengan awan yang tebal dan bermula ketika angin menggiring kawanan awan kecil ke zonaconvergence. Kemudian pengarakan awan tersebut menyebabkan bertambahnya jumlah uap dalam perjalanannya terutama pada zona. Apabila dua awan atau lebih menyatu, maka arus udara yang naik dalam awan akan bertambah secara umum, hal tesebut menyebabkan datangnya tambahan uap dari bagian bawah dasar awan yang memiliki peran menambah potensi yang terpendam untuk berakumulasi. Awan tebal akan bergerak kemana saja yang Allah kehendaki, sedangkan faktor akumulasi dan pembangunannya akan terus-menerus sepanjang arus udara yang naik mampu membawa formasi awan dari titik-titik ari, atau butiran embun. Ketika angin tidak lagi mampu membawa formasi tersebut maka proses akumulasi terhenti dan hujan pun turun ke bumi. $^{36}$

\section{Tafsir al-Azhar}

Adapun penafsiran HAMKA pada kata hujan dalam ayat tersebut ialah hujan yang turun kebumi tersebut keluar dari celah-celah gumpalan tersebut dengan proses tekumpulnya awan setelah bercerai-berai, awan yang berisikan uap itu menjadi hitam pekat dan Allah jatuhkan sesuai dengan kehendak-Nya. ${ }^{37}$

\section{Analisis Komparatif}

Secara garis besar penafiran dari tiga mufassir terhadap ayat diatas menjelaskan bahwa, turunnya hujan ke bumi tentunya dengan berbagai proses yang telah ditetapkan oleh Allah Swt diantaranya ialah dengan angin yang menggerakkan awan untuk menyatu dengan bergumpal-gumpal, maka dengan kehendak Allah keluarlah dari gumpalan-gumpalan awan tersebut air hujan yang

\footnotetext{
35 ibn Katsir, Tafsir Ibnu Katsir, 6, 384.

${ }^{36}$ Shihab, Tafsir Al-Misbah, 9, 89-90.

${ }^{37}$ Hamka, Tafsir Al-Az̧har, 7 (Jakarta: Gema Insani Press, 2015), 77.
} 
membasahi bumi. Dari penjelasan di atas sudah jelas bahwa di dalam ayat dan penafsiran ada beberapa indikasi yang mengategorikan bahwa makna hujan pada ayat tersebut ialah sebagai fenomena alam. Perbedaan dari tiga penafsir tersebut ada pada tafsir al-Misbah yang mana dalam menjelaskan ayat diatas tampak lebih panjang dalam memaparkan peroses terjadinya hujan dari awal hingga turunnya air hujan tersebut.

\section{Kesimpulan}

Dari pemaparan di atas dapat disimpulkan, ternyata kata hujan yang ada dalam Alquran tidak selalu bermakna rahmat/anugerah, namun juga bermakna sebagai azab dan kejadian alam. Secara kontekstual, penafsiran Ibn Katsir, Quraish Shihab, dan HAMKA memiliki banyak kesamaan. Perbedaannya hanya pada aspek redaksi dalam menguraikan makna dari term hujan. Baik hujan yang dimaknai sebagai rahmat atau azab keduanya memiliki asbab dan itu sangat berhubungan dengan cara manusia bersikap. Bila hujan sebagai rahmat, manusia dituntut untuk selalu bersyukur dan mentadabburi kasih sayang Allah yang menurunkan hujan, sedangkan sebagai azab, hendaknya manusia membenah diri, dan memaknainya juga sebagai bentuk kasih sayang Allah.

\section{Bibliografi}

Alfiyah, Avif. "Metode Penafsiran Buya Hamka Dalam Tafsir Al-Azhar.” Jurnal Ilmiah Ilmu Usbuluddin 15, no. 1 (2016). doi:http://dx.doi.org/10.18592/jiiu.v15i1.1063.

Baidan, Nasiruddin. Metode Penafsiran Alquran. Yogyakarta: Pustaka Pelajar, 2002.

Hamka. Tafsir Al-Ažbar, 3. Jakarta: Gema Insani Press, 2015.

- Tafsir Al-Azhar, 4. Jakarta: Gema Insani Press, 2015.

. Tafsir Al-Azhar, 6. Jakarta: Gema Insani Press, 2015.

- Tafsir Al-Azhar, 7. Jakarta: Gema Insani Press, 2015.

—. Tafsir Al-Azhar, 8. Jakarta: Gema Insani Press, 2015.

Iqbal, Muhammad. "Metode Penafsiran Alquran M. Quraish Shihab." TSAQAFAH 6, no. 2 (November 30, 2010): 248-70. doi:10.21111/tsaqafah.v6i2.120.

Iskandar, Rezki Apriliya. "Sandiaga Uno: Allah Lagi Kirim Hujan, Harusnya Jadi Berkah." Liputan 6. Accessed December 16, 2017. https://www.liputan6.com/news/read/3192188/sandiaga-uno-allahlagi-kirim-hujan-harusnya-jadi-berkah.

Katsir, Imaduddin Abi al-Fida Isma'il ibn. Tafsir Ibnu Katsir, 9. Jakarta: Pustaka Imam Syafi'i, 2004.

_. Tafsir Ibnu Katsir, 4. Jakarta: Pustaka Imam Syafi'i, 2004. 
—. Tafsir Ibnu Katsir, 6. Jakarta: Pustaka Imam Syafi' 'i, 2004.

—. Tafsir Ibnu Katsir, 7. Jakarta: Pustaka Imam Syafi'i, 2004.

Khalwani, Ahmad, Mohamad Yusuf Ahmad Hasyim, and Ahmad Miftahuddin. "Kata Bermakna Hujan Dalam Al-Quran (Tinjauan Semantik Dan Stilistika)." Lisanul' Arab: Journal of Arabic Learning and Teaching 6, no. 1 (May 15, 2017): 1-5.

Muharam, Ahmad Taufiq. "Proses Turunnya Hujan Dalam Alquran: Telaah Penafsiran Tantawi Jauhari Dalam Tafsir Jawāhir Fi Tafsīr Qur'an AlKarīm.” UIN Sunan Kalijaga, 2008. http://digilib.uinsuka.ac.id/1681/1/BAB\%20I\%2C\%20V\%2C\%20DAFTAR\%20PUST AKA.pdf.

Nurdin, Nurdin. "Analisis Penerapan Metode Bi Al-Ma'sur Dalam tafsir Ibnu Katsir Terhadap Penafsiran Ayat-Ayat Hukum.” Asy-Syir'ah 47, no. 1 (January 1, 2013). doi:10.14421/asy-syir'ah.2013.\%x.

Othman, Mohd Sukki, Asrul Azam Shafie, and Muhd Zulkifli Ismail. "Makna Perkataan Hujan Dalam Al-Quran Berdasarkan Konteks Situasi." Jurnal Kemanusiaan 15, no. 1-S (November 27, 2017). https://jurnalkemanusiaan.utm.my/index.php/kemanusiaan/article/vie $\mathrm{w} / 260$.

Salim, Mula. Metodologi Ilmu Tafsir. Sleman: Teras, 2005.

Sani, Ridwan Abdullah. Sains Berbasis Alquran. Jakarta: Bumi Aksara, 2015.

Shihab, M. Quraish. Tafsir Al-Misbah, 4. Jakarta: Lentera Hati, 2002.

. Tafsir Al-Misbah, 9. Jakarta: Lentera Hati, 2002.

Simatupang, Oktolina. "Pesan Tentang Edukasi Bencana Dalam Film 'Nyanyian Musim Hujan." Journal Penelitian dan Pengembangan Komunikasi dan Informatika 17, no. 2 (2016): 12. doi:http://dx.doi.org/10.31346/jpkp.v17i2.706.

Sofyan, Muhammad. Tafsir Wa Al-Mufassirun. Medan: Perdana Publishing, 2015.

Sugono, Dedy. Kamus Besar Bahasa Indonesia. Jakarta: Gramedia Pustaka Utama, 2008.

Syamil, Tim. Alquran Terjemah Al-Syamil. Bandung: Syaamil Qur'an, 2012.

Wartini, Atik. "Corak Penafsiran M. Quraish Shihab Dalam Tafsir AlMisbah.” HUNAFA: Jurnal Studia Islamika 11, no. 1 (June 19, 2014): 109-26. doi:10.24239/jsi.v11i1.343.109-126.

Yulianti, Eny, and Elok Kamilah Hayati. Kasih Sayang Allah Dalam Air Hujan. Malang: UIN-Malang Press, 2008. 